\title{
Preparing and Storing an Emergency Safe Drinking Water Supply ${ }^{1}$
}

\section{Shuchi Shukla and Thomas Obreza ${ }^{2}$}

\section{Introduction}

The purpose of this fact sheet is to emphasize the importance of having a personal safe drinking water supply during an emergency, and to describe the steps that Florida's citizens should take to prepare and store drinking water.

\section{Why store water?}

- Occasionally, Florida is affected by severe weather systems like hurricanes or other natural disasters. In their wake, people can be left without electric power and/or running water for days or weeks at a time.

- Humans can survive a scarcity of food for weeks, but cannot go without water for more than a few days.

- During a natural disaster, normal drinking water supplies can quickly become contaminated without notice.

- The best strategy for an impending emergency is to collect and store a personal safe drinking water supply.

\section{How much water should be stored?}

- If your normal water source becomes unavailable or if you are unsure about its fitness to drink, you will need an alternative clean water supply for drinking, food preparation, and personal hygiene.

- You should store enough clean water to allow each person in the household to use 1 to 1.5 gallons per day.

- Increase the amount stored if there are children, sick people, nursing mothers, and/or pets in the household.

- You should store a minimum 3-day supply of water.

- Example: A four-person household requiring 1.5 gallons per person per day for 3 days would need to store $4 \times 1.5 \times 3=18$ gallons.

1. This document is SL220, a fact sheet of the Soil and Water Science Department, Florida Cooperative Extension Service, Institute of Food and Agricultural Sciences, University of Florida. Original publication date: October 2004. Visit the EDIS Web Site at http://edis.ifas.ufl.edu.

2. Shuchi Shukla, Engineer, and Thomas Obreza, Professor, Soil and Water Science Department, Florida Cooperative Extension Service, Institute of Food and Agricultural Sciences, University of Florida, Gainesville, FL 32611-0290.

The Institute of Food and Agricultural Sciences (IFAS) is an Equal Employment Opportunity - Affirmative Action Employer authorized to provide research, educational information and other services only to individuals and institutions that function without regard to race, creed, color, religion, age, disability, sex, sexual orientation, marital status, national origin, political opinions or affiliations. For information on obtaining other extension publications, contact your county Cooperative Extension Service office. Florida Cooperative Extension Service / Institute of Food and Agricultural Sciences / University of Florida / Larry R. Arrington, Interim Dean 


\section{What containers can be used to store water?}

- Water should be stored before a disaster occurs, in thoroughly sanitized food-grade plastic or glass containers:

1. First, wash the inside and outside of each container with soap and hot water.

2. Next, sanitize containers with a solution of 1 teaspoon of non-scented household bleach per quart of water.

3. Finally, rinse thoroughly with plain clean water.

- Avoid using milk containers because they can be hard to clean. Bacteria can grow quickly in a milk container, contaminating the water stored in it. However, if there is no alternative, special care should be taken when sanitizing these containers.

- Avoid using bleach containers for drinking water storage because they are not made of food-grade plastic. Water stored in them to use for washing could mistakenly be used for drinking, with serious consequences.

\section{Do I need to disinfect (add chemicals to) the water?}

- If your drinking water comes from a public supply, no chemical disinfectant is needed. An exception is if an emergency "boil water" notice has been given, in which case you would need to disinfect the water before storing it (see below).

- Although properly stored public-supply water should have an indefinite shelf life, replace it every 6 to 12 months for best taste.

- If the water you are storing comes from a private well, spring, or other untested source, purify it before storage to kill bacteria (see below).

\section{How should water be stored?}

- After containers have been filled with clean water, mark them with the words "Drinking Water" and indicate the date of storage.

- Direct heat and light can slowly damage plastic containers resulting in eventual leakage, so they should be stored in a dark, cool and dry place.

- Container caps should be tightly secured.

- Store water away from gasoline, kerosene, pesticides or similar substances because vapors from these materials can penetrate plastic.

- Water can also be stored in a freezer. Frozen water provides the added benefit of helping to keep frozen food cold for a longer time if power is out for an extended period. Use only plastic containers to store water in a freezer, as glass may not be able to withstand the pressure of expanding ice.

\section{How is water kept safe once a container is opened?}

- To minimize exposure to bacteria, open a container just before use and then refrigerate it if power is available. If no refrigeration is available, keep the container up high, away from children and pets.

- Use water from opened containers within 1 to 2 days if possible.

\section{When is disinfection of water necessary?}

- If your drinking water comes from a public supply and a "boil water order" has not been issued, you can assume that it is safe to drink.

- If there is any possibility that your water source has been contaminated, do not use it for drinking, preparing food, or brushing teeth.

- Sometimes the appearance of water can be a reason for concern. If water appears murky, cloudy or has a foul taste or smell, it is likely that it is contaminated. Do not consume this water; use an alternative clean source instead. 


\section{How can water be purified (disinfected)?}

\section{Boiling water}

Boiling water is the most common way to destroy potential pathogens.

- Water boiled continuously for 3 to 4 minutes can be stored in a suitable container at room temperature.

- Aeration can improve the flat taste of boiled water. Aerate water by transferring water back and forth from one container to another.

\section{Chemical treatments}

Chemical treatments like chlorination and iodine tablets are also popular ways to purify water.

- Chlorinate water using basic household bleach (5.25\% sodium hypochlorite) that is unscented and free of any other cleaner or color-safe component. The table below represents the recommended amount of bleach to be used to disinfect water. After mixing in the bleach, let the water stand for 30 minutes. A slight chlorine odor should be detectable after the treatment. If not, treat the water again and let it stand for 15 more minutes.

\begin{tabular}{|lcc|}
\hline \hline \multirow{2}{*}{ Amount of water } & \multicolumn{2}{c|}{ Amount of bleach } \\
\cline { 2 - 3 } & Clear water & Cloudy water \\
\hline 1 quart & 2 drops & 4 drops \\
1 gallon & 8 drops & 16 drops \\
5 gallons & $1 / 2$ teaspoon & 1 teaspoon \\
\hline \hline
\end{tabular}

- Iodine tablets will eradicate heat-resistant pathogens. Iodine purification is more convenient and faster than chlorination, but it has limitations:

1. The safety of long-term use of iodine tablets is not yet established

2. Some people are allergic to iodine

3. Iodine is not safe for pregnant women or people with thyroid disease.

\section{Distillation and filtration}

Distillation and filtration are newer procedures compared with boiling. In these cases, water is treated physically rather than chemically.

- Distillation involves collection of vapor from boiling water followed by condensation back to a liquid. The condensed water does not contain any impurities that may have been in the raw water. The "flat" taste of distilled water can be improved by aerating it.

- Filtration is a simple process where water is passed through a filter to remove impurities. Mechanical filters like strainers and sediment filters are effective in removing debris and some suspended solids.

\section{Reverse osmosis}

- Activated carbon filtration systems combined with reverse osmosis (RO) are effective in removing total dissolved solids (TDS), turbidity, asbestos, lead, and other heavy metals.

- RO filters can remove pathogens of all sizes, but are not specifically designed to do so. Do not rely on an RO water treatment system to remove pathogens from contaminated water.

\section{Summary}

- Preparing for an emergency requires only a little awareness and effort.

- Storing water prior to an impending disaster is one of the most important things you can do.

- If an emergency situation is imminent, every household should have at least a 3-day supply of drinking water stored.

- Water from public supplies and bottled water are safe to store without purification.

- Water from a well or spring should be purified before storing.

- Containers used to store water must be clean and food-grade. 
- The easiest ways to purify water are to boil it or add basic household bleach.

\section{References}

Beem, Marley, M. Fram, B. Brown, and A.

Guest. "Emergency Water Supplies."

Oklahoma Cooperative Extension Service. Fact

Sheet F-1519.

Care 2 Make a Difference: Reverse Osmosis

Water Filtration. Retrieved Oct 07, 2004 from

http://www.care2.com/channels/solutions/home/ 86

Miner, Dorothy L. Emergency Drinking Water Supplies. North Carolina Cooperative Extension Service.

Smith, George F. "Safe Drinking Water in an Emergency." University of Tennessee, Agricultural Extension Service. AE\&RD No. 26. 